12.

\title{
HRVATSKA HISTORIJA, JEZIK I \\ KULTURA U IZVJEŠTAJU TALIJANSKOG \\ KONZULA BRUNE ZUCULINA (1943)
}

\section{ALBERTO BECHERELLI}

UDK: 308(497.5)“1943“(047)

PREGLEDNI ČLANAK

Sažetak: Autor analizira izvještaj La Croazia, koji je 1943. godine napisao konzul Bruno Zuculin, na službi u Odsjeku za stranu štampu Ministarstva narodne kulture Italije. Izvještaj, napisan po dogovoru ministarstava vanjskih poslova NDH i Italije, sadrži odjeljke o hrvatskoj geografiji, ekonomiji, stanovništvu, religiji, književnosti i umjetnosti, jeziku, gradovima i selima, folkloru, Poglavniku i ustašama, ulozi NDH u Evropi i odnosima između Italije i $\mathrm{NDH}$. Važno je svjedočanstvo o tadašnjoj talijanskoj interpretaciji hrvatske historije i stvaranju NDH. Iako su tokom Drugog svjetskog rata Nezavisna Država Hrvatska i Kraljevina Italija oficijelno bili saveznici, njihov odnos je bio obilježen brojnim nesuglasicama. Izvještaj La Croazia predstavlja pogled talijanskog diplomate na hrvatsku historiju i kulturu, a napisan je s ciljem da doprinese saradnji i prijateljstvu Italije i NDH. Zuculin piše o stoljetnim umjetničkim i književnim vezama Hrvata i Talijana i o utjecaju talijanske umjetnosti na hrvatsku. Zastupa teoriju o iranskom porijeklu hrvatskog naroda, umjetnom stvaranju Jugoslavije i slavi Pavelića kao obnovitelja Hrvatske. Daje egzotične i skoro mistične opise hrvatskog naroda, tradicionalnih nošnji i običaja.

Ključne riječi: Italija, NDH, Bruno Zuculin, propaganda, 1943.

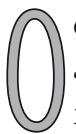

djel za stranu štampu Ministarstva narodne kulture Italije (Direzione Generale della Stampa Estera, Ministero della Cultura Popolare) poslao je 1. septembra 1943. godine izvještaj La Croazia Ministarstvu vanjskih poslova Italije. Tekst o hrvatskoj historiji, politici i kulturi, koji je napisao konzul Bruno Zuculin u službi gorenavedenog odjela, nastao je na osnovu dogovora ministarstava vanjskih poslova Italije i NDH. ${ }^{1}$ Iako ovaj izvještaj, završen u veoma važnom historijskom momentu za Italiju, između sloma fašističkog režima (25. juli 1943) i kapitulacije Italije (8. septembar 1943), nema veliku književnu vrijednost, iznimno je važno svjedočanstvo o tadašnjoj talijanskoj interpretaciji hrvatske historije i stvaranju NDH. Do sada nikad nije korišten u proučavanju odnosa

\footnotetext{
Nepoznat je datum kada je napisan ovaj izvještaj (vjerovatno na proljeće 1943), kao i datum kada je postignut dogovor između ministarstava vanjskih poslova Italije i NDH.
} 




Slika 1. Bruno Zuculin o Argentini 1949. godine: fascinacija narodima i zemljama

Italije i NDH, a danas se nalazi u Historijskoj i diplomatskoj arhivi Ministarstva vanjskih poslova u Rimu (Archivio Storico Diplomatico del Ministero degli Affari Esteri). ${ }^{2}$ Sastoji se od 67 stranica, a sadrži odjeljke o hrvatskoj historiji (od samih početaka do $\mathrm{NDH}$ ), geografiji, ekonomiji, stanovništvu (također i o hrvatskoj dijaspori), religiji (odnosima između katolika, pravoslavnih i muslimana), književnosti i umjetnosti, jeziku, folkloru, Poglavniku i ustašama, te o ulozi NDH u Evropi i odnosima Italije i Hrvatske. Dio izvještaja čine opisi sela i gradova u NDH (opisi Zagreba, Karlovca, Dubrovnika, Sarajeva i Mostara) i detalji o hrvatskom i bosanskom folkloru (narodnim plesovima, muzici i tradicionalnim festivalima). ${ }^{3}$

Autor izvještaja Bruno Zuculin, rođen u Rimu 1885. godine, do tada je stekao veoma bogato iskustvo u konzularnim poslovima kojima se počeo baviti 1908 . U novembru 1908. godine radio je u konzulatu u Aleksandriji u Egiptu, a od jula 1910. zamjenik je konzula u Prizrenu. Između novembra 1915. i marta 1924. godine bio je konzul u Florianopolisu (Brazil), Mendozi (Argentina), New Orleansu (SAD) i Pernambucu (Brazil). ${ }^{4}$ Radio je i kao delegat talijanske Nacionalne agencije za turizam (Agenzia Nazionale del Turismo, skraćeno ENIT), a posjećivao je i Balkan: Beograd, Skoplje i Zadar. Napisao je nekoliko knjiga o Južnoj Americi i njenim resursima poput, na primjer, knjige L'Argentina e le sue ricchezze (Argentina i njena bogatstva).

Njegov izvještaj predstavlja ne samo njegov pogled nego i pogled talijanskih fašističkih diplomata na hrvatsku povijest i kulturu. ${ }^{6}$ Poznato je da su NDH i Italija tokom Drugog svjetskog rata oficijelno bili saveznici, što je legalizirano Rimskim ugovorom 18. maja 1941.

\footnotetext{
Archivio Storico Diplomatico Ministero degli Affari Esteri, Rim (dalje ASDMAE), Gabinetto del Ministro e Segreteria Generale, 1923-1943, AP 29, b. 1494, Ministero della Cultura Popolare, Direzione Generale per il Servizio della Stampa Italiana, a Ministero Affari Esteri, Gabinetto, Divisione III, prot. n. 2620, oggetto: Disciplina delle pubblicazioni, Roma, 1 settembre 1943, n. 1 allegato, La Croazia, Bruno Zuculin.

3 Sadržaj: I - Un po' di storia (Historija); II - Un po' di geografia (Geografija); III - L'economia croata (Hrvatska ekonomija); IV - Cattolici, musulmani e ortodossi (Katolici, muslimani i pravoslavci); V - Letteratura e arti (Književnost i umjetnost); VI - Le città e la campagna (Gradovi i sela); VII - Usi e costumi (Običaji i nošnje); VIII - Il Poglavnik e gli ustascia (Poglavnik i ustaše); IX - Il ruolo della Croazia in Europa (Uloga Hrvatske u Evropi); X - La Croazia e l'Italia (Hrvatska i Italija).

ASDMAE, Bollettini del personale del Ministero degli Affari Esteri.

Bruno ZUCULIN, L'Argentina e le sue ricchezze, Firenze 1949.

${ }_{6}$ Slične stavove koje je Zuculin iznio u izvještaju imali su npr. i Raffaele Casertano, talijanski diplomat i poslanik u NDH i Eugenio Coselschi, vođa fašističke misije u Hrvatskoj. Vidjeti Alberto BECHERELLI, Italia e Stato Indipendente Croato (1941-1943), Roma 2012.
} 
godine, ali njihov odnos je bio obilježen bitnim neslaganjima, među kojima je najvažnije bilo dalmatinsko pitanje. Napetosti nije bilo samo između Rima i Zagreba, već i između talijanskih oficira i talijanskih diplomata u Hrvatskoj. Postojala je velika razlika u interpretaciji događaja između talijanskih diplomata - pogotovo onih u Zagrebu, koji su podržavali ustaški režim skoro do samog kraja 1943. godine - i talijanskih oficira u okupiranoj Jugoslaviji. Talijanska diplomatska delegacija u Zagrebu je kritizirala prosrpske stavove koje su postepeno prihvatali neki talijanski oficiri i vojnici. Od samog početka talijanski oficiri su bili veoma kritični prema ustaškim saveznicima i Pavelićevoj vladi, najviše zbog progona Srba i Jevreja, jer je to, smatrali su oni, bio razlog širenja ustanka u NDH. S druge strane, ustaške vlasti su krivile Talijane za četnički i partizanski ustanak jer su smatrali da su njihovi saveznici bili preblagi prema Srbima i Jevrejima. ${ }^{7}$

U Zuculinovom tekstu, koji je napisan s potrebom da stabilizira savezničku saradnju i prijateljstvo između Italije i NDH, ove nesuglasice se ne spominju. Zuculin piše o stoljetnim umjetničkim i književnim vezama između Hrvata i Talijana te o odnosima koji su se u prethodne tri godine, tj. od nastanka NDH, znatno učvrstili. Kako bi NDH, „država u kojoj žive ljudi koji su stoljećima povezani s Italijom", ${ }^{8}$ bila poznatija Talijanima, autorica Amy Bernardy napisala je knjigu Croazia e Roma (Hrvatska i Rim), koju je izdao Istituto per le Relazioni Culturali con l'Estero (Institut za kulturne odnose s inozemstvom) u Rimu.' Zuculin spominje ovu knjigu namijenjenu široj publici jer su u njoj detaljno objašnjeni stoljetni odnosi između Italije i Hrvatske. ${ }^{10}$ Piše i o hrvatskim intelektualcima i umjetnicima kao što su Strossmayer, Mažuranić, Meštrović, ali se naročito fokusira na neke renesansne pisce, najupečatliivije primjere povezanosti talijanske i hrvatske kulture. Pored toga što spominje hrvatske duhovne i svjetovne dokumente iz XIV stoljeća, piše i o hrvatskoj poeziji iz XV stoljeća koja je, kako kaže, rezultat kontakta dubrovačke kulture s talijanskom „spiritualnošću”. Dubrovnik je mjesto i prvih hrvatskih petrarkista, dok je u Splitu djelovao Marko Marulić, čiji je najpoznatiji ep Judita štampan u Veneciji 1521. godine, dvadeset godina nakon što je napisan. Hvar, treći najveći grad u to doba u Dalmaciji, kolijevka je pjesnika. Tamo je Hanibal Lucić napisao dramu Robinja, dok je u Zadru Petar Zoranić napisao roman Planine (1538). ${ }^{11}$ Zuculin govori i o Collegium hungarico-illyricum, koji je 1553. godine osnovao zagrebački biskup u Bologni, a gdje su mladi Hrvati studirali teologiju, filozofiju, pravo i medicinu. Zuculin ističe kako je svake godine bilo sve više hrvatskih studenata, koji su kasnije postajali biskupi, književnici i znanstvenici. ${ }^{12}$ Spominje i zlatno doba hrvatske književnosti u XVII stoljeću u Dubrovniku, zadržavajući se na Ivanu Gunduliću, imitatoru Tassoa, Juniju Palmotiću i Ivanu Buniću Vučiću. Bilo je to, kako kaže, „bogato i raznovrsno stvaralaštvo, koje je izražavalo narodne osjećaje i čiji su pisci imitirali talijansku književnost". ${ }^{13}$ Kada je riječ o XVIII stoljeću, Zuculin, pored ostalih pisaca, govori i o Andriji Kačiću Miošiću iz Makarske, čije je djelo Razgovor ugodni naroda slovinskoga do XX stoljeća bilo jedno od najčitanijih hrvatskih knjiga. Kaže da „prava hrvatska nacionalna književnost” počinje u Zagrebu u XIX stoljeću s Ivanom Mažuranićem, koji je

Generalno o odnosima Italije i NDH vidjeti: Nada KISIĆ-KOLANOVIĆ, NDH i Italija. Političcke veze i diplomatski odnosi, Zagreb 2001.

B. ZUCULIN, La Croazia, 54.-55.

Amy A. BERNARDY, Croazia e Roma, Roma 1941.

B. ZUCULIN, La Croazia, 64.-65.

Isto, 36.-38.

Isto, 64.-65.

Isto, 37. 
u epu Smrt Smail-age Čengića evocirao borbe između Turaka i Crnogoraca, a pored njega spominje i Petra Preradovića, Stanka Vraza i Dimitrija Demetra. Važnost historijskog romana Augusta Šenoe Zlatarevo zlato poređuje s važnošću romana Alessandra Manzonija I promessi sposi (Zaručnici). ${ }^{14}$

Kada je riječ o politici, Zuculin piše o utjecaju koji su Giuseppe Garibaldi i Giuseppe Mazzini imali na vođe hrvatskog risorgimenta Antu Starčevića i Eugena Kvaternika. Pored toga, ističe da je dugogodišnje progonstvo, koje je Ante Pavelić proveo u Italiji, uvelike djelovalo na njega i da je upravo taj boravak, duži od deset godina, razlog zašto je Pavelić odlučio ponuditi hrvatsku krunu članu talijanske kraljevske dinastije Aimoneu od Savoje, kojeg, kako Zuculin piše, „svi Hrvati vole kao kralja Hrvatske”. ${ }^{15}$

Veliki dio rada Zuculin je posvetio hrvatskoj historiji te, na kraju, posebno usponu Ante Pavelića. ${ }^{16} \mathrm{U}$ prvom odjeljku posvećenom historiji Hrvata, Zuculin govori o iranskom porijeklu naziva Hrvat. Na mjestu grada Azov, gdje rijeka Don utječe u Azovsko more, nalazila se grčka kolonije Tanais. U arheološkim istraživanjima prije 1943. pronađeni su nadgrobni natpisi s imenima Horoath i Horovath. Autor ističe da su se neki historičari složili da ta dva imena pripadaju osobama hrvatskog plemena, koje se na to područje naselilo zbog trgovine između II i III stoljeća. Smatra se da je ovo hrvatsko pleme živjelo između Kavkaza i Azovskog mora, u priobalnom području, gdje su se, u Zuculinovo vrijeme, vodile teške borbe između Nijemaca i Rumuna protiv Rusa 1942-1943. Ovo pleme, kako Zuculin piše, pripadalo je kavkaskim narodima i među prvima je krenulo $s$ tog područja na kraju IV stoljeća. Riječ hrvat, piše Zuculin, iranska je i znači prijatelj ili saveznik. Autor povezuje ovo značenje sa činjenicom da su Hrvati, kao i Anti, bili saveznici Hunima, kada su Huni došli u Panonsku nizinu. Nakon smrti Atile 543. godine, dodaje se u izvještaju, Hrvati i Anti oslobodili su se Huna te podrvgnuli Slavene pod svoju vlast, prihvatajući njihov jezik i običaje. ${ }^{17}$

Nastavlja da su Hrvati, izmiješani sa Slavenima, stvorili hrvatsku naciju sa slavenskim jezikom, koja je bila podijeljena na dvije države: Veliku Hrvatsku ili Bijelu Hrvatsku („bijela boja u iranskom jeziku povezana je sa zapadom" ${ }^{18}$ i Malu Hrvatsku ili Crvenu Hrvatsku („boja koja za Iračane predstavlja jug”). ${ }^{19}$ Idući prema zapadu, Hrvati su došli u kontakt s Gotima, germanskom plemenskom skupinom koja je u tom periodu bila naseljena kod rijeke Visle. S njima su se vrlo zbližili. Zuculin tvrdi i da su hrvatska imena koja se završavaju na mir naslijeđe odnosa između Gota i Hrvata, jer mir na gotskom znači blistav i nije povezan $s$ istoimenom slavenskom riječju. ${ }^{20}$ Bliskost $s$ Gotima korištena je među ustašama kao dokaz da su Hrvati germanskog, a ne slavenskog porijekla.

Nakon što je opisao historiju Hrvata u Srednjem vijeku i u Habsburškoj Monarhiji, te njihovu borbu protiv Osmanlija, autor se skoncentrisao na rano dvadeseto stoljeće, Prvi

14 Isto, 36.-38.

15 Isto, 36.-38. O tome vidjeti: A. BECHERELLI, Italia e Stato Indipendente Croato, 94. O Aimoneu od Savoje vidjeti: Giulio VIGNOLI, Il sovrano sconosciuto. Tomislavo II Re di Croazia, Milano 2006. Riječ je o oficijelnoj propagandističkoj formulaciji jer je talijanski princ pod Mussolinijevim pritiskom i pritiskom kralja Vittorija Emanuela III prihvatio ovu ulogu kao Tomislav II. Princ nikada nije bio u Hrvatskoj, gdje je bio praktično nepoznat.

${ }_{16}$ Za analizu Zuculinovog teksta korištene su sljedeće knjige o historiji Hrvatske: Josip HORVAT, Politička povijest Hrvatske, Zagreb 1989.; Ivo GOLDSTEIN, Croatia: a History, London 1999.; Branka MAGAŠ, Croatia Through History. The Making of a European State, London 2007.

17 B. ZUCULIN, La Croazia, 1.-2.

18 Isto.

19 Isto.

20 Isto. 
svjetski rat i „umjetno stvaranje Kraljevine Jugoslavije s nasilnim pokušajima ujedinjenja jezika". ${ }^{21}$ Piše da su se Hrvati suprotstavili procesu asimilacije u srpsku državu, smatrajući da je to kršenje njihovog prava za samoopredjeljenje. Politički program u Beogradu, piše Zuculin, je bio pansrpski, po kojem su oslobađanje i ujedinjenje Južnih Slavena bili samo integracija drugih nacija u Veliku Srbiju. ${ }^{22}$ U Kraljevini Srba, Hrvata i Slovenaca (SHS) najvažnija hrvatska politička partija je bila Hrvatska pučka seljačka stranka (HPSS), koju su osnovali braća Stjepan i Antun Radić 1904. godine. Iako je to bila miroljubiva politička partija, koja je predstavljala hrvatske interese pred beogradskom vlašću, inicirala je masovne političke prosvjede. ${ }^{23}$ Zuculin ne spominje da su Hrvati, politički slabi, bili prisiljeni prihvatiti uslove iz Srbije za stvaranje Kraljevine Srba, Hrvata i Slovenaca, kako bi se zaštitili od talijanskih teritorijalnih i strateških aspiracija na hrvatsku obalu Jadranskog mora. ${ }^{24}$

Zuculin smatra da je oko 1925. stvorena nova duhovna atmosfera, čemu je najviše doprinio Mile Budak, jedan od najistaknutijih političara u NDH, koji je napisao roman Ognjište. Među nasljedovateljima dalmatinske poezije, čiji je centar bio u Dubrovniku, bili su Olinko Delorko, zatim Viktor Vida i Ivo Lendić, koji su živjeli u Rimu, i „najveći od svih pjesnika” Vladimir Nazor, s otoka Brača, cijenjen kao pjesnik „hrvatske nacionalne borbe” i odličan prevoditelj Dantea, Carduccija, Pasturesa i D’Annunzja. U vrijeme kada je nastao ovaj izvještaj, Nazor se već pridružio partizanima, ali Zuculin, da bi prikrio istinu, piše da su ga partizani, zapravo, zarobili. ${ }^{25}$

Druga polovica 1920-ih bila je iznimno teška za Hrvatsku seljačku stranku (HSS) i Stjepan Radić je počeo pregovore za formiranje koalicije sa Narodnom radikalnom strankom (NRS). Odluka HSS-a da napusti odlučnu opozicijsku politiku i dogovori kompromis s Beogradom bila je teško prihvatljiva za hrvatski narod i HSS je izgubila prestiž među Hrvatima. Jugoslavenski unutarnji sukob dosegao je vrhunac 20. juna 1928. godine, kada je u parlamentu radikal Puniša Račić ubio hrvatske zastupnike Pavla Radića i Đuru Basaričeka, a ranio Stjepana Radića, koji je preminuo nešto kasnije. Kralj Aleksandar Karađorđević je 6. januara 1929. godine proglasio diktaturu. Promjena naziva države - Kraljevina Jugoslavija umjesto Kraljevine Srba, Hrvata i Slovenaca - trebala je olakšati jačanje osjećaja pripadnosti ljudi različitih nacionalnosti jedinstvenoj državi. Kraljeva politika je dovela do još većeg nezadovoljstva u zemlji i ubrzala razvoj različitih nacionalnih pokreta.

Prema Zuculinu, to sve ubrzava uspon Ante Pavelića, „,oditelja pokreta za nezavisnost Hrvatske i obnovitelja hrvatske države”, ${ }^{26}$ kojem autor posvećuje čitav jedan odjeljak. Veliča

Isto, 9.-11.

22 Isto.

23 O Kraljevini Jugoslaviji vidjeti i: Stephen CLISSOLD, Storia della Jugoslavia. Gli slavi del sud dalle origini a oggi, Torino 1969.; Ivo BANAC, The National Question in Yugoslavia. Origins, History, Politics, Itacha - London 1984.

24 Od kraja 19. stoljeća talijanski strateški ciljevi su bili uspostava prevlasti na području Mediterana, što je podrazumijevalo koloniju na sjevernoj obali Afrike i ekspanzionističku politiku na Balkanskom poluostrvu. Napetost između Italije i Kraljevine Srba, Hrvata i Slovenaca nastala je krajem Prvog svjetskog rata, kada se raspala Austro-Ugarska Monarhija, zbog područja na istočnoj obali Jadranskog mora na kojim je živjelo etnički izmiješano stanovništvo. Rapalskim ugovorom (12. novembar 1920) Italija je anektirala zapadni dio Kranjske, Istru, Trst, Zadar i dalmatinske otoke Lošinj, Cres i Lastovo, a Rijeka je trebala postati slobodna država, čime je prekinuta okupacija Gabriela D’Annunzija. Rimskim ugovorom (27. januar 1924) Italiji je pripala Rijeka, a Sušak Kraljevini Srba, Hrvata i Slovenaca. Tekst Rapalskog ugovora vidjeti: Amedeo GIANNINI, Documenti per la storia dei rapporti fra l'Italia e la Jugoslavia, Roma 1934., 36.-45. O Gabriele D’Annunziju, okupaciji Rijeke i Jadranskom pitanju vidjeti Paolo ALATRI, Nitti, D'Annunzio e la questione adriatica (1919-1920), Milano 1959.; Michael A. LEDEEN, D'Annunzio a Fiume, Roma - Bari 1975.

25 B. ZUCULIN, La Croazia, 36.-38.

26 Isto, 59. 
Pavelićevo ponašanje, njegove jednostavne geste, smirenost te spori i mirni način govora, koji je uvijek isti, bez obzira kome se obraćao - vojniku, narodnim masama ili gostu. Pored osnovnih informacija o njegovom životu, u kojima je Pavelić opisan kao osoba koja je oslobodila Hrvatsku, autor hvali i Pavelićevo pisanje, nazivajući ga poetskim, hvaleći Pavelića kao sjajnog pisca i poznatog odvjetnika. ${ }^{27}$ Njegova je najvažnija knjiga Errori e orrori, napisana na talijanskom jeziku i objavljena pod pseudonimom u Sieni 1937/1938. Prevedena je na hrvatski i objavljena u Zagrebu 1941. godine pod naslovom Strahote zabluda. ${ }^{28} \mathrm{Knjiga}$ je ocijenjena kao detaljno i pomno proučavanje doktrinarnih i praktičnih grešaka komunizma, u čemu se, kako piše Zuculin, može vidjeti utjecaj Ante Starčevića.

U poglavlju Poglavnik i Ustaše Zuculin povezuje ustašku ideologiju s ideologijom Ante Starčevića i njegovom Hrvatskom strankom prava (HSP), u kojoj je Pavelić započeo svoju političku karijeru. Za pisca je nesporno da ustaška ideologija ima svoje korijene u hrvatskom nacionalizmu XIX stoljeća ${ }^{29}$ i u Starčevićevim idejama. Ustaška ideologija je svoje shvaćanje hrvatstva Bosne i Hercegovine povezivala sa Starčevićevim, kao i podjelu bosanskohercegovačkih Hrvata na dvije etnokonfesionalne komponente - katoličku i muslimansku. Dobro je poznato da je Starčević tvrdio da je Bosna i Hercegovina bila neodvojiva od Dalmacije i da je pripadala hrvatskom srednjovjekovnom kraljevstvu. Prema Starčeviću su bosanski muslimani bili najbolji Hrvati, dio hrvatskog naroda najčǐ̌će hrvatske krvi. Zbog ovih i drugih razloga i danas pojedini historičari Starčevića i Kvaternika smatraju ideološkima precima ustaša. ${ }^{30}$

Zuculin s jedne strane piše o snažnom utjecaju Talijana na Hrvate, ali u isto vrijeme pruža vrlo egzotične i gotovo mistične opise hrvatskog naroda, s posebnim naglaskom na spasonosnu krepost hrvatskih seljaka i seoskog društva, što je bila i srž ustaške i nacističke propagande. Pavelić je započeo ustaški pokret s aksiomom da je Hrvatska zemlja seljaka. ${ }^{31}$ Zuculin posvećuje velik dio teksta tradicionalnim običajima i narodnoj nošnji Hrvata. Ističe da nije jedini koji to čini, jer su tokom posljednjih 150 godina autori knjiga i članaka o Hrvatskoj uvijek spominjali nošnje koji su se mogle vidjeti na Trgu bana Jelačića u Zagrebu. Autor također hvali Etnografski muzej u Zagrebu, koji je, prema njemu, nedvojbeno najzanimljivije mjesto koje turisti mogu posjetiti u glavnom gradu Hrvatske. Kaže da su ove nošnje, koje su se nosile prije nego je kapitalistička ekonomija ušla u Hrvatsku sredinom XIX stoljeća, u doba kada su se život i rad temeljili na kućnim zadrugama, izrazi života na selu i svjedoci drevnih narodnih običaja, koji se ljubomorno čuvaju već stoljećima.

27 Isto, 59.-63.

28 U Italiji 2009. ponovo je, u istoj verziji iz 1941. godine, izdana knjiga Strahote zabluda u izdanju izdavačke kuće radikalne desnice Sentinella d'Italia: Ante PAVELIĆ, Errori e orrori: comunismo e bolscevismo in Russia e nel mondo, Roma 1941.

29 O hrvatskom nacionalnom pokretu u XIX stoljeću vidjeti: Bogdan KRIZMAN, The nationality problem in the Habsburg Monarchy in the 19th century: the Croats as an integrating and disintegrating force, Zagreb 1965.; Beniamino SALVI, Il movimento nazionale e politico degli Sloveni e dei Croati: dall'Illuminismo alla creazione dello Stato jugoslavo (1918), Trieste 1971.; Angelo TAMBORRA, L'Europa centro-orientale nei secoli XIX-XX (1800-1920), Milano 1971.

30 Ovo se odnosi na one autore koji pišu da su ustaše slijedile Starčeviće teze o bosanskohercegovačkim Muslimanima kao „cvijetu hrvatskog naroda” (Marcus TANNER, Croatia. A Nation Forged in War, New Haven - London 1997. 148.; Ivo GOLDSTEIN, Hrvatska 1918.-2008., Zagreb 2008., 234.), otvoreno opisuju Stračevića kao rasistu (Marco A. RIVELLI, L'Arcivescovo del genocidio. Monsignor Stepinac, il Vaticano e la dittatura ustascia in Croazia, 1941-1945, Milano 1998., 14.; Mirjana GROSS, Izvorno pravaštvo - ideologija, agitacija, pokret, Zagreb 2000., 690.-750.; Pino ADRIANO - Giorgio CINGOLANI, La via dei conventi. Ante Pavelić e il terrorismo ustascia dal Fascismo alla Guerra Fredda, Milano 2011., 22.-23.) ili čak tvrde da je Starčević svojevrsni ante litteram ustaša (Karlheinz DESCHNER, Die Politik der Päpste im XX Jahrhundert, Leck 1991.; Stefano PETRUNGARO, Riscrivere la storia. Il caso della manualistica croata (1918-2004), Aosta 2006.).

31 B. ZUCULIN, La Croazia, 59.-63. 
Autor posebno hvali raznolikost lokalnih kostima koji svugdje odražavaju boje lokalnog krajolika: zlatna boja žita dominira u ravnicama Slavonije; bijelo i crveno grožđe u brdima; bijela i crna ovčja vuna u planinama Like i u Dinarskom gorju. Pored boja, razlikuju se također i materijali. U nekim regijama prevladavaju metalni lanci, dok u ostalima koraljne ogrlice, perle, vune i dr. ${ }^{32}$

Autor naglašava da svaka pojedinost proizlazi iz duboke simbolike, u kojoj se prožimaju paganstvo i kršćanstvo; cvijeće, lišće, grožđe, jaja, kukuljice, ljudsko oko u kombinaciji s raspelom u različitim izvedbama i bojama daju različita značenja. Na primjer, crveni krug označava sretno oko i želju ljubavnika, dok je zeleni krug mačje oko i obilježava prevaru i štiti od nesreće. Zuculin objašnjava i neka lokalna praznovjerja, koja su opet simbolična: ako trudna žena nosi svijetle ukrase za pojasom, ona želi da dijete ima plave oči, a crni ukrasi označavaju crne oči. Simbolika se, prema njegovim riječima, ne nalazi samo u kostimima, već i u bojama ženske odjeće, frizurama i $\mathrm{dr}^{33} \mathrm{Na}$ nekoliko mjesta autor ponavlja važnost crvene boje u tradicionalnim nošnjama i običajima Hrvatske. Navodi da mladi preferiraju ovu boju jer simbolizira sunce, život i snagu, a nakon prve noći mladenka nosi crvenu haljinu s crvenom kapom koja simbolizira nevinost koju nudi mladoženji (postoji sličan običaj na Siciliji). ${ }^{34}$ Piše i o tradicionalnim nošnjama muškaraca, koje se također mogu vidjeti u Bosni i Hercegovini, zatim o narodnim plesovima, tipičnim muzičkim instrumentima guslama i gajdama i mnogim običajima u kojima se miješaju paganstvo i kršćanstvo. Kaže da su rođenje, sklapanje brakova i smrt bili popraćeni velikim ceremonijama, a strogo su se pratili i tradicionalni obredi za istjerivanje zlih duhova koji bi mogli naštetiti djetetu ili uništiti sreću novog bračnog para. ${ }^{35}$ Spominje i nacionalne igre poput moreške, kumpanije i alke, koja je najpoznatija jer se igrala stoljećima, bez prekida. Autora alka podsjeća na Saracenski boj u Arezzu (giostra del saraceno) i druge srednjovjekovne igre u Italiji. Detaljno opisuje uzbuđenje i slavlje turnira, koji se u njegovo vrijeme održavao u Sinju, a koji slavi pobjedu nad Turcima 1715 . godine. ${ }^{36}$

Na kraju izvještaja, u odjeljku o ulozi Hrvatske u Evropi, autor piše da Hrvatska ne želi biti i da nikada nije niti bila dodatak Balkanu, jer je hrvatska misija isključivo evropska (pri čemu Evropa znači Zapad). Hvali hrvatsku ekonomiju, politički i vojni sistem te navodi da su u nekoliko godina samostalnog života Hrvati pokazali političku i vojnu zrelost razoružavajući „srpsku vojsku” (jugoslavensku) i boreći se protiv gerilaca. Slavi hrvatsku vojsku koja ima vrlo staru i jaku vojnu tradiciju; hrvatski pukovi borili su se u Rusiji pod zapovjedništvom Napoleona i pod Austro-Ugarskom. ${ }^{37}$ On opisuje Hrvate kao otvorene, lojalne, ljubazne i gostoljubive te navodi da se talijanski jezik, a naročito venecijanski dijalekt kojim se u Dalmaciji pričalo u mnogim porodicama, sve više koristio u Hrvatskoj. Zbog ovog razloga Zuculin je smatrao da bi Hrvatska, nakon završetka rata, mogla postati i jedna od glavnih turističkih destinacija za Talijane. Da je ova ideja već bila prisutna potvrđuje i turistički vodič o Hrvatskoj za Talijane Guida della Croazia, tiskana u nakladi Consociazione Turistica Italiana (C.T.I.) 1942. godine. ${ }^{38}$ Govori i da će Hrvatska postati poznatija Talija-

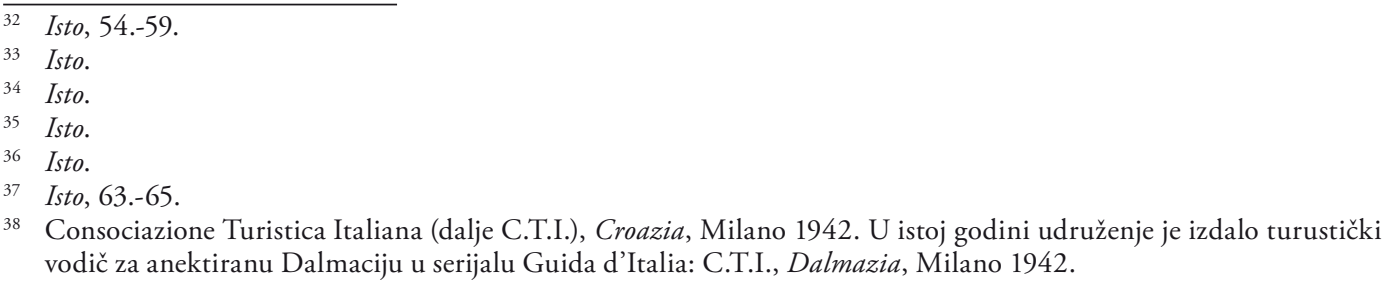
vodič za anektiranu Dalmaciju u serijalu Guida d'Italia: C.T.I., Dalmazia, Milano 1942. 
nima s radom Talijanskog kulturnog instituta u Zagrebu, kursevima i konferencijama koje organizuje te planiranim posjetama poznatih književnika i saradnjama mladih hrvatskih pjesnika i Ungarettijeve škole moderne poezije. ${ }^{39}$

Iako u ovom tekstu Zuculin daje brojne informacije o hrvatskoj geografiji, ekonomiji, jeziku, hrvatskim i bosanskim gradovima, ovaj esej se najviše fokusirao na one dijelove koje govore o odnosima Italije i NDH, odnosima između Talijana i Hrvata te o utjecaju Italije na Hrvatsku. Tekst pokazuje kako su talijanske institucije tog perioda oficijelno doživljavale Hrvatsku. ${ }^{40}$ Zuculin je napisao izvještaj kojeg karakteriše pomalo skrivena propaganda fokusirana da naglasi tačke kontakta između zajedničkog kulturnog i historijskog naslijeđa i da smanji nesuglasice, koji je tih godina bilo nekoliko. Prije svega, postojalo je dalmatinsko pitanje i za Talijane je bilo nemoguće od Hrvata napraviti najbolje saveznike na Balkanu kad su im istovremeno nastojali oduzeti Dalmaciju, koju su Hrvati smatrali kolijevkom svoje civilizacije. U vremenu kada je Zuculin napisao rad i poslao ga talijanskim institucijama u kasno ljeto 1943. godine Italija je doživjela slom svojih imperijalističkih aspiracija. Zuculin u zaključku piše da će „hiljade i hiljade talijanskih oficira i vojnika”, koji su se snažno borili s domobranima i ustašama protiv partizana i „pobunjenika”, i na taj način spoznali „kvalitete srca i duše” ovog hrvatskog „bratskog naroda”, postati pioniri u razvoju bliskih odnosa i saradnje između ove dvije države. ${ }^{41}$ Piščev vlastiti zaključak dokazuje da i nakon dvije godine od potpisivanja Rimskog ugovora odnosi između Hrvata i Talijana nisu bili onakvi kakvi bi trebali biti prema Ugovoru.

\section{$\cos$}

\section{Croatian history, language and CUlture in THE ITALIAN CONSUl BRUNO ZuCULIN'S REPORT (I943)}

The author anylises the report entitled La Croazia, written in 1943 by the long-serving consul of the Italian Ministry of Cultura Popolare, Bruno Zuculin. The report, whose creation was agreed upon by the Ministries of Foreign Affairs of Italy and the Independent State of Croatia (NDH) includes paragraphs on Croatian geography, economy, population, religion, literature and art, language, its cities and countryside, its folklore, the Poglavnik and the Ustashe, the role of NDH in Europe and the relations between Italy and NDH. Although it was commissioned especially for that occasion, it serves as an important testimony of the Italian view of Croatian history and the creation of NDH during World War II. During World War II, Croats and Italians were officially allies, but their relations were burdened by numerous conflicts which stemmed from unresolved fundamental questions, the most important of which was the dispute over Dalmatia. The La Croazia report sheds light on the issue from the point of view of the Italian diplomats and it was written with the aim to contribute to the spirit of friendship and collaboration between the two countries. Zuculin writes about the centuries-long relations between Italian and Croatian poets

39 B. ZUCULIN, La Croazia, 64.-65. Giuseppe Ungaretti je bio jedan od najvažnijih talijanskih pjesnika dvadesetog stoljeća. Zbog svoje odanosti fašizmu i odnosa s Mussolinijem 1942. postao je profesor moderne i savremene književnosti na Univerzitetu u Rimu. Oko njegove katedre formirana je grupa intelektualaca, koji su se kasnije isticali svojim kulturnim aktivnostima i akademskim karijerama.

40 Kakav je taj odnos zaista bio, drugo je pitanje, koje nije predmet ovog članka.

41 B. ZUCULIN, La Croazia, 66.-67. 
and artists, as well as the influence of Italian art on the Croatian. He mentions the Iranian origin of the Croatian people, the artificial creation of Yugoslavia and praises Pavelić as the liberator of Croatia. He also gives exotic and almost mystical descriptions of Croatian people, their traditional costumes and customs.

Keywords: Italy, NDH, Bruno Zuculin, propaganda, 1943

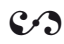

\section{Literatura}

Pino ADRIANO - Giorgio CINGOLANI, La via dei conventi. Ante Pavelić e il terrorismo ustascia dal Fascismo alla Guerra Fredda, Milano 2011.

Paolo ALATRI, Nitti, D’Annunzio e la questione adriatica (1919-1920), Milano 1959.

Ivo BANAC, The National Question in Yugoslavia. Origins, History, Politics, Itacha - London, 1984.

Alberto BECHERELLI, Italia e Stato Indipendente Croato, Roma 2012.

Amy A. BERNARDY, Croazia e Roma, Roma 1941.

Bollettini del personale del Ministero degli Affari Esteri.

Stephen CLISSOLD, Storia della Jugoslavia. Gli slavi del sud dalle origini a oggi, Torino 1969.

Consociazione Turistica Italiana, Croazia, Milano 1942.

Consociazione Turistica Italiana, Dalmazia, Milano 1942.

Karlheinz DESCHNER, Die Politik der Päpste im XX Jahrhundert, Leck 1991.

Amedeo GIANNINI, Documenti per la storia dei rapporti fra l'Italia e la Jugoslavia, Roma 1934.

Ivo GOLDSTEIN, Croatia: a History, London 1999.

Ivo GOLDSTEIN, Hrvatska 1918.-2008., Zagreb 2008.

Josip HORVAT, Politicka povijest Hrvatske, Zagreb 1989.

Nada KISIĆ-KOLANOVIĆ, NDH i Italija. Političke veze i diplomatski odnosi, Zagreb 2001.

Bogdan KRIZMAN, The nationality problem in the Habsburg Monarchy in the 19th century: the Croats as an integrating and disintegrating force, Zagreb 1965.

Michael A. LEDEEN, D’Annunzio a Fiume, Roma - Bari 1975.

Branka MAGAŠ, Croatia Through History. The Making of a European State, London 2007.

Ante PAVELIĆ, Errori e orrori: comunismo e bolscevismo in Russia e nel mondo, Roma 1941.

Stefano PETRUNGARO, Riscrivere la storia. Il caso della manualistica croata (1918-2004), Aosta 2006.

Marco A. RIVELLI, L’Arcivescovo del genocidio. Monsignor Stepinac, il Vaticano e la dittatura ustascia in Croazia, 1941-1945, Milano 1998.

Beniamino SALVI, Il movimento nazionale e politico degli Sloveni e dei Croati: dall'Illuminismo alla creazione dello Stato jugoslavo (1918), Trieste 1971.

Angelo TAMBORRA, L'Europa centro-orientale nei secoli XIX-XX (1800-1920), Milano 1971.

Marcus TANNER, Croatia. A Nation Forged in War, New Haven - London 1997.

Giulio VIGNOLI, Il sovrano sconosciuto. Tomislavo II Re di Croazia, Milano 2006.

Bruno ZUCULIN, L'Argentina e le sue ricchezze, Firenze 1949.

Bruno ZUCULIN, La Croazia. Archivio Storico Diplomatico Ministero degli Affari Esteri, Roma (ASDMAE), Gabinetto del Ministro e Segreteria Generale, 1923-1943, AP 29, b. 1494. 